\title{
아일랜드 ODA 현황
}

아일랜드 개발협력단(Development Cooperation Ireland)이 최근 발간한 2004년 연례 보고서 (Annual Report)에 따르면 아일랜드는 2004년에 양 자 및 다자간 협력 프로그램을 통해 총 4 억 8,800 만 유로 규모의 대외원조(ODA)를 집행한 바, 주요 내용 은 아래와 같음.

\section{I. 아일랜드 ODA 지원 규모}

마일랜드는 총 대외원조 예산의 $50 \%$ 를 최빈국에 지원하고 있고, UN이 설정한 기준(GNP의 $0.15 \%)$ 을 초과하여 최빈국에 원조를 하는 세계 6 대국의 하나임. 또한 $\mathrm{OECD}$ 회원국 중 9 번째의 공여국임.

- 총 ODA 지원액(2004년):4억 8,800만 유로

- 2003년에는 4억 4,500만 유로 지원

- GNP당 ODA 비율:0.40\%

- GNP(2004년):1,220억 유로

\section{II. 양자 협력 프로그램}

1. 개요

ㅁ 아일랜드는 2004년에 양자 협력 프로젝트를 통해 미개발국에 3 억 2,900 만 유로를 지원함.

- ODA 지원 프로그램은 에티오피아, 레소토, 모 잠비크, 탄자니아, 우간다 및 잠비아 등 사하라

이남 최빈국과 동티모르(2003년 이후)에 집중 2004년도 지원사업은 HIV/AIDS 고아 등 개도국 내 취약 계층인 아동들에 대한 교육, 건강 보호에 중점을 두어 추진됨.

- 개도국 내 교육 프로그램에 대한 지원규모는 총 원조예산의 $13 \%$ 정도

\section{2. 국가별 지원 현황}

ㅁ에티오피아

- 2004년에 2,750만 유로 지원

- 인구 3 만 6,000 명당 의사가 1 명인 현실을 감안, 자격을 갖춘 의료 인력을 각 지방에 파견하는 방 
안 검토 중

- 현재까지 2,800 명이 파견되었고, 7 천여명이 연수 중

모ㅈㅏㅏㅁ비크

- 2004년 2,840만 유로 지원

- 아일랜드 정부는 8년간 모잠비크에 대해 공적 지원을 해왔으며 빈곤 감소를 위해 새로운 Country Strategy Paper(CSP 2004 2006)를 입안, 추진 중

ㅁ탄자니아

- 2004년 2,200만 유로 지원

- 2004년은 탄자니아 지원을 시작한 지 25년이 되는 해로서 탄자니아 정부의 빈곤 감소 전략 (Poverty Reduction Strategy)' 에 따라 지역 개발, 인권, 농업, 건강 및 교육 등에 중점적으로 지원

무ㄱㅏㅏㄴㄷㅏ

- 2004년 3,070만 유로 지원

- 우간다 정부의 '빈곤 근절 활동계획(PEAP:

Poverty Eradication Action Plan)' 과 연계하 여 정부 기능 증대, 사법, 부패 방지 및 민주화 등을 촉진하고 북우간다 분쟁 종식을 위한 안보 및 갈등 해결 능력 향상에 중점을 두고 있음.

$\square$ 기타

- 잠비아에 1,660십만 유로, 레소토에 1,060만 유 로, 동티모르에 370만 유로, 남아공에 950만 유 로, 짐바브웨에 70만 유로, 발칸 지역 및 CIS에 620만 유로, 팔레스타인에 200만 유로 지원

\section{3. 긴급 재난 구조기금}

미진, 해일 등 자연재해 발생시, 아일랜드는 인도 적 차원의 긴급 재난 지원을 하고 있으며 2004년 에는 약 40 여개 재난 피해국에 3,800 만 유로를 지원함.

- 아프리카: 24.6 백만 유로

- 아시아:4.3백만 유로

- 중동지역:1.3백만 유로 등

ㅁㅡㅡㄱㅎㅣ 지난해 쓰나미 사태 발생시, 아일랜드는 1 백 만 유로를 즉시 지원하였고 Ahern 총리는 2005 년도 ODA 예산에 구조기금으로 1천만 유로를 추 가할 것이라고 밝힌 바 있음.

\section{NGO 지원}

ㅁ 아일랜드는 관련 NGO들을 통한 개도국 지원을 활 성화하고 있는 바, 2004년 주요 NGO(CONCERN, Christian Aid, GOAL 등)들이 추진 중인 개도국 지원 프로젝트(MAPS:Multi Annual Programme Scheme)에 약 3,800 만 유로를 지원함.

\section{III. 다자간 협력 프로그램}

1. 개요

마일랜드는 2004년 EU, UN 및 기타 국제기구를 통해 1 억 5,900 만 유로를 지원

\section{EU 차원의 협력}

ㅁ아일랜드는 2004년 상반기 EU 의장국으로서 개 
발협력분야에서의 정책적 우선 순위를 빈곤, $\mathrm{HIV} / \mathrm{AIDS}$ 근절 및 아프리카와의 협력 증진에 두 고 $\mathrm{EU}$ 개발 협력장관 회의(2004년 6월)를 개최하 는 등 최빈국 지원을 위해 노력하였으며, 2004년 에 7,400만 유로의 개발기금을 $\mathrm{EU}$ 집행위에 납 부함.

\section{UN 및 관련 국제 기구를 통한 지원}

1) UN

2004년 2월, 아일랜드 개발협력단 및 보건부는 UNICEF, UNAIDS, WHO의 후원하에 Breaking the Barriers-Partnership to Fight HIV/AIDS in Europe and Central Asia' 라는 제하의 각료 회담을 개최한 바 있으며, 2004년 UN(UNDP, UNICEF, UNHCR, UNAIDS, WHO 등)에 4,300 만 유로의 자발적 기여금을 납부함.

\section{2) UN 농업 및 식량 기구}

\section{가. UN 식량 농업 기구(FAO)}

마일랜드는 2004년 FAO 활동을 위해 약 148 만 유로를 지원함.

- 연례 기여금:91만 유로

- 우역(牛疫) 근절을 위한 프로그램(Global Rinderpest Eradication Programme) 지원액: 25 만 유로

- FAO/WHO 신탁 기금:3만 유로 등

\section{나. 세계 식량 프로그램(WFP)}

2004년에 약 1,050 만 유로의 기여금을 납부함.
- 개발협력단 기여금: 4.4 백만 유로

- 농업부 기여금:6.09백만 유로

\section{다. 국제 농업 개발기금(IFAD)}

ㅁ 2004년에 37만 유로 지원

\section{IV. 관찰 및 평가}

마일랜드 대외원조 사업은 모두 무상원조(Grant) 이며 외교부 내 개발협력단(DCI:Development Cooperation Ireland)이 전담하여 수행하고 있음. 또한 아일랜드는 총 ODA 규모의 약 $67 \%$ (3억 2,900 만 유로) 정도를 양자간 채널을 통해 개도국 에 지원하고 있으며, 정부 차원의 직접적인 대외원 조뿐 아니라 관련 $\mathrm{NGO}$ 의 활동을 지원하는 형태 로 공적 원조를 수행하고 있음.

2004년 총 ODA 규모는 4억 8,800만 유로로서 2003 년의 4 억 4,500 만 유로에 비해 약 $9.6 \%$ 가 증 가한 바, 특히 2005년 ODA 예산으로 5억 4,500만 유로를 편성한 점을 감안시, 아일랜드의 대외원조 규모는 앞으로도 꾸준히 지속될 것으로 전망됨.

[자료:주아일랜드 대사관] 